\title{
Current Trends And Future Considerations Of Higher Education In Business
}

Paul J. Carruth, (E-mail: pcarruth@ selu.edu), Southeastern Louisiana University Ann K. Carruth, (E-mail: acarruth@selu.edu), Southeastern Louisiana University

\begin{abstract}
Graduate programs in business, while still highly regarded, are under increased scrutiny by both business academics and the corporate world. There is growing evidence that graduate business programs are not responsive to the needs of the business community. The complexity and global nature of business today requires that schools must provide their graduates with not only traditional managerial skills, but also skills relating to the interpersonal and conceptual. These essential skills include the ability to team build, to effectively communicate ideas, and to embrace cultural diversity. To remain relevant and viable, business schools must assess not only their teaching, but also the content of their research. Their focus should be on establishing criteria of excellence that benefits not the business school or faculty, but rather those that hire their graduates. The purpose of this paper is to examine some of the basic assumptions of graduate business education today, and provide recommendations for enhancing its relevance in today's complex business environment. Perspectives that influence these trends are analyzed and include the changing mission of graduate programs in business as well as the debate over specialization versus integration of graduate business courses.
\end{abstract}

\section{INTRODUCTION}

raduate schools of business, especially top-ranked programs, have historically been highly regarded by both the academic and business world. Highly selective admission standards for entering students and lucrative job offers for graduating students added to the prestige of graduate schools of business. Today, however, schools of business face much scrutiny and criticism concerning their failure to provide the type of relevant learning experience needed by students in today's complex business world.

Disturbing signals for schools of business in the U.S. include declining applications and falling enrollments. Applications to thirty of the top MBA programs in the country are down nearly $30 \%$ overall since 1998 with some top schools experiencing as much as a 50\% reduction in applicants. To adapt, some schools have reduced the number of students that enter their program each year. Other programs that once admitted only 20 to $25 \%$ of their applicants have been forced to accept up to 35\% (Merritt, 2005). While tuition costs have increased in recent years far in excess of the general rate of inflation, individuals have generally viewed graduate school as an investment in their future. An MBA should provide an individual not only with a credentialed status and valuable networking connections, but a career enhanced by the acquisition of new knowledge and skills that should far exceed the cost of the degree. But a significant number of individuals in both the academic and business world have begun to question the value of the traditional MBA program as it is currently taught.

For graduate schools of business, the message being communicated to them could be that companies are unhappy with the outdated training and education that they are providing. An increasing number of companies are choosing to train their employees in-house, not just because of cost savings, but also because of the failure of business schools to teach the knowledge and principles they deem essential in today's competitive world (Business Week, 2005). In the last decade alone, many factors ranging from the restructure of corporate governance to globalization have resulted in an increasingly complex business world. If the purpose of an MBA is simply to provide an added credential to a student's resume, then reform is not really needed. But, if the purpose is to produce leaders with a 
broader societal perspective that helps them make crucial decisions in this complex business environment, then graduate schools of business need to adapt and reform in order to meet these challenges. The purpose of this paper is to examine some of the basic assumptions of graduate education in business today, and analyze recommendations for enhancing its relevance in today's complex business environment.

\section{THE CHANGING MISSION OF GRADUATE PROGRAMS IN BUSINESS}

The year 1959 marked the beginning of a gradual change in the manner in which business schools re-defined academic excellence. In that year, the Ford Foundation and the Carnegie Corporation issued reports that were critical of business schools for their lack of academic rigor. Their criticisms suggested that business schools had middling students and indifferent faculty, and their inadequate academic research made them little more than vocational colleges (Tyson, 2005). The foundations also provided recommendations as to how schools of business could establish respectable academic programs and even provided grants to assist in this endeavor. In the years following those reports, the top business schools in the country shifted their focus toward academic research and the establishment of programs of academic distinction. The shift away from defining quality based on the capability of business graduates and the business acumen of faculty to that related primarily to the academic rigor of faculty research and publications changed the culture of business schools. Today, many top business schools recruit, tenure, and promote only individuals that publish in highly quantitative academic journals, rather than those who publish in professional journals where their work and ideas may actually influence the business workplace. This system of academic rewards results in a faculty devoted to research with little interest in the practicalities of real business life.

Most business schools define their mission as including both teaching and research. The purpose of academic research in business schools should be to provide new information and insight into organizational behavior that can provide a benefit to business and society. Researchers can expand the boundaries of knowledge, and some of what is published in top rated academic journals is first-rate and important. But much of it is primarily complex statistical presentations that focus on very narrow esoteric topics that are of interest only to other academics. Some critics argue that business academics have taken simple models of human and corporate behavior and developed mathematical models for the purpose of appearing scientific in order for their discipline to earn academic respectability. In the view of some, this approach establishes a mere pretense of knowledge, where in fact no real knowledge and understanding exists (Economist, 2005). Unfortunately, as a result of this, business executives in the real world must look outside academics for ideas and solutions to real world issues. Some of the best minds in the country are found in the nation's top business schools, and yet because of the narrow focus of their academic work, society derives little benefit from their scholarly efforts. In an ironic twist of fate, by studying issues of interest only to themselves and of no real benefit to business executives, academic business faculty are establishing their own irrelevance. The consequences of having full time graduate business faculty that are qualified to teach only courses in academic research and methodology are now beginning to unfold. Employers are starting to recognize that MBAs are lacking in the business skills and understanding of human relations that their companies need. Executives are beginning to wonder if business academics are even engaged in the same profession as the students they send forth into the business world.

Research is a vital component of the role that universities serve in our society. However, there is a decided need to establish a balance between the academic rigor of business research and its practical relevance. Business schools need to recognize that applied research that is well written and well documented and published in highly respected practitioner journals can be as valuable as highly quantitative papers written only for a small audience of other business academics. Business research that is both useful and readily accessible to business executives and practitioners is essential for business schools to re-establish their relevancy. A new model must be introduced that balances the need for relevance to the business profession with the rigor of academic research (Bennis and O'Toole, 2005). In order to accomplish this, business schools need to establish new standards of excellence for faculty, and establish polices related to recruitment, tenure, and promotion of faculty that reward these standards. 


\section{DECLINING INTEREST IN MBA PROGRAMS}

Graduate programs today must address a myriad of constituent concerns. These concerns include excessive tuition, excessive number of adjunct faculty, and excessive emphasis placed on program rankings. This section will address these concerns in order to offer some insight into possible factors that may be related to the declining interest in MBA programs.

A recent survey of full time MBA programs indicated that there was an average decline in the number of applications of 33\% between the years of 2002 and 2004 (Badenhausen and Kump, 2005). Even top-tier schools such as Dartmouth, Northwestern, and Harvard saw significant declines in applications of $47 \%$, 44\%, and $31 \%$ respectively. The decline in applications can be attributed in part to dramatically increasing cost associated with obtaining a MBA. Tuition for earning a degree full-time at a top-tier program can cost up to $\$ 70,000$ plus $\$ 130,000$ in lost income. Furthermore, the base starting salary for MBAs has stagnated in the last four years and a significantly smaller percentage of students are able to obtain jobs by graduation (Badenhausen and Kump, 2005.) This is due in part because there is a subtle trend among employers to hire and promote talented workers that do not possess the MBA degree. A growing number of large firms are studying the issue of whether MBAs perform better than undergraduates that receive internal training. In fact, a recent survey of 1,521 senior executives found that $57 \%$ of the respondents felt that to get ahead in their companies, having an MBA was "nice, but not necessary." And, a significant number (17\%) indicated that having an MBA was "unimportant" (Fisher, 2005).

Another factor affecting the quality of graduate education in business today is the fact that many business schools are utilizing adjunct faculty more than ever. For example, recent figures revealed that the Business School at Columbia University had eighty-nine adjuncts compared to one hundred fifteen full time faculty, Yale School of Management had 30 of 84 faculty that were adjuncts, and at the Graduate School of Business at the University of Virginia approximately one-third of its faculty were adjuncts (Chambers, 2004). It is often much more cost effective to have lower paid adjuncts teach than it is to hire additional full time faculty. In addition, many schools are forced to hire adjuncts due to a shortage of terminally qualified business professors. Fewer students are getting doctorates in business than ten years ago, resulting in fewer full time teaching and research oriented faculty. To fill the gap, many business schools hire practicing businessmen that are able to relate real world experiences. However, courses taught by business executives, while entertaining, often lack the academic rigor associated with classes conducted by full time faculty with advanced degrees. Furthermore, practitioners teaching part time often are not readily available outside of class for student consultations. While it is true that after many years in academics some full time professors can seem detached from the real world of business, students attend college to get an academic degree. Full time faculty are expected to stay up to date with current research in business to enable them to teach complex and essential business topics. Too few classes taught by full time teachers and researchers, and too many taught by entertaining adjuncts could result in a diminished college experience for students. To avoid diminishing their academic integrity, it is important that schools of business maintain a proper balance of full time and adjunct faculty.

A third factor affecting business education is the fact that in recent years administrators have become concerned about, if not consumed by, various national ratings of colleges of business. These rankings help schools to achieve national recognition for their programs. Ratings of business schools include surveys of students concerning their experiences and satisfaction. But this process presumes that students somehow know what kind of education is in their best interest. It assumes that they have the ability to compare their program with other programs they have not attended. It assumes that students have the ability to properly evaluate and judge faculty performance. It assumes that students know more about the process of learning than the institution does. This approach actually has the effect of undermining the quality of higher education (Across the Board, 2005). If college faculty are continually evaluated on how well regarded they are by students, the rigor and challenge of the course may be compromised.

In addition, one of the important criteria used in the rankings relates to the number of applications and number of acceptances to a program. As a result, business schools are obligated to recruit large numbers of applicants in order to have a low acceptance rate. Schools are also rated on the basis of average scores on the GMAT entrance exam. And yet, faculty know that GMAT scores do not represent a meaningful predictor of success in the business world. Not surprisingly, some schools have even reduced the size of their MBA program in order to maintain a low 
acceptance rate and high GMAT scores. Thus, while schools vie for the best graduate students, their selection process may actually be counterproductive to achieving this goal (Feldman, 2005).

\section{SPECIALIZATION VERSUS INTEGRATION OF GRADUATE BUSINESS COURSES}

There is an ongoing debate concerning the educational objectives that should be achieved by graduate programs in business. The debate often centers around whether the MBA should be an academic degree program or a training ground for new business employees. Under pressure from companies that hire graduate business students, a significant number of prestigious universities have reduced the core curriculum to allow more electives that provide early specialization. Administrators at some elite business schools argue that specialization makes students more employable because it helps them develop marketable business skills and not just general business knowledge (Middleton, 2004). Thus, to respond to the changing needs of businesses, a new variety of executive education courses are being offered by some university business schools. To better serve the professional development of managers, shorter more specialized courses that are tailored to specific industries are replacing some of the more general course offerings. Rather than having students from a variety of unrelated industry groups studying a broad array of topics ranging from marketing to finance, some of the leading business schools are now experimenting with a more focused approach that customizes the curriculum for executives in specific industries (Gard, 2005). The primary benefit of such niche programs is that participants are able to focus on practical applications that can benefit them more directly in their jobs than is generally available when participants come from a variety of different industries (Howatson, 2005).

However, the favorable view toward the development of specific business skills through early specialization in the MBA program is not universal. Opponents of this trend argue that students are being shortchanged in that they are not gaining the broad core of business perspectives needed to succeed in the long term. Narrow specialization of study by students may serve the immediate needs of some employers and thus give some students an advantage in obtaining their first job, but a more vocational degree is more likely to produce middle managers rather than corporate leaders in the long run.

The MBA degree as offered in the United States has come under increasing scrutiny in recent years. Many business programs seem bound by the traditional core areas of accounting, finance, and marketing. Yet this approach often results in the unmet needs of corporations in the highly competitive global business world of the $21^{\text {st }}$ Century. Critics of this approach argue that students primarily learn how to crunch numbers, and that MBA programs in general fail to adequately address the important people skills such as teamwork, negotiations, and developing empathy for others (Stern, 2004). These are the skills that can result in success or failure for executives in the real world. And yet, business schools have struggled in their efforts to implement these areas in the core curriculum. In fact a recent survey of the top 50 U.S. business schools revealed less than a third require non-traditional, non-number crunching courses like human resource management, negotiations, leadership, and entrepreneurship (Navarro, 2004).

As early as 1988, some observers recommended that business schools should provide an integrated education, rather than an assortment of individual discipline related courses (Porter and McKibbin, 1988). Many business schools have made efforts to implement this advice, and yet for the most part the results have been merely new courses with integrative-sounding names conducted by several professors teaching independent segments one following the other. Thus today, many MBA students are given homework assignments that fail to help them integrate the information before them (Feldman, 2005). Many colleges are graduating students that are trained to think that they can still manage through analysis of financial ratios. Yet, today in Corporate America there is a great demand for executives who can manage creativity among employees. Outsourcing, fast changing technology, and evolving customer expectations require that companies quickly adapt the way they operate. Presidents of large corporations must have managers that can supervise innovation and direct strategic design teams (Business Week, 2005).

Graduate programs in business should prepare students to think creatively and address problems from a variety of perspectives. To fully develop students, faculty must provide an environment of constant challenges that force students to nurture their own creativity. Business students must be made aware that the world is dynamic, not 
fixed, and rather than following a series of pre-ordained steps to success, they have the opportunity to create success for themselves and their companies through imagination, hard work, and an understanding of the human aspect of business.

\section{CONCLUSION}

The global business world is one of ever changing demands and expectations. For business schools to maintain their relevance they must be adaptive. They must provide their graduates with not only traditional managerial skills, but also skills relating to the interpersonal and conceptual. Business schools must assess not only their teaching methods, but also the content of their research, and must develop measures of quality in terms that benefit not the school nor the faculty members, but rather the businesses that hire their graduates. The focus of higher education should be on problem solving, and not just information (Babu, 2005). For graduate schools of business to remain viable, they must be readily able to adapt to changing demands and expectations of their constituents. Just like businesses, universities need the ability to reinvent themselves when called upon to do so by the shifting global business environment (Tyson, 2005).

An astonishing range of attributes are needed by today's business executive. Therefore, if graduate schools of business are going to be the provider of executive education in the future, they must be up to the challenge of providing students with more than just specialized knowledge of the basic functional areas of business. They must provide their students with the skills to act upon such knowledge. But equally important, they must instill in their students essential leadership attributes such as veracity, sound judgment, insight, and the ability to think innovatively. These are the challenges that lay before graduate schools of business. Their ability to meet these challenges will determine whether they continue to be the chosen form of executive education.

\section{REFERENCES}

1. $\quad$ Across the Board. 2005. "Hardly Academic." Across the Board (May/June): Vol. 42, Issue 3, 47(6).

2. Babu, T.D. 2005. "An Analytical Study of the Teaching Methods at Affiliated B-Schools in Hyderabad and Secunderabad.” Journal of Services Research (April-September), Vol. 5, Number 1, 101(22).

3. Badenhausen, Kurt and Kump, Lesley. 2005. "Part-Time Fever." Forbes (September 5): Vol. 176, No. 4, 148(4).

4. Bennis, Warren G. and O’Toole, James. 2005. "How Business Schools Lost Their Way." Harvard Business Review (May): Vol. 83, Issue 5, 96(9).

5. Berman, Phyllis. 2005. "Now It’s Time To Get Your Hands Dirty." Forbes (February, 28): Vol. 175, Issue 4, 90(2).

6. $\quad$ Business Week. 2005. "B-Schools for the $21^{\text {st }}$ Century." Business Week (April 18): Issue 3929, 112.

7. $\quad$ Chambers, Erin. 2004. “Too Much of a Good Thing.” Business Week (October 18): Issue 3904, 94.

8. Feldman, Daniel C. 2005. "The Food's No Good and They Don't Give Us Enough: Reflections on Mintzberg's Critique of MBA Education." Academy of Management Learning \& Education (June): Vol. 4, Issue 2, 217(4).

9. $\quad$ Fisher, Anne. 2005. “Will Going to B-School Help Me Win a Big Raise?” Fortune (May 2): Vol. 151, Issue 9,34 .

10. Gard, Lauren. 2005. “A Better Fit For Exec Ed.” Business Week (March 14): Issue 3924, 106(2).

11. Howatson, Rob. 2005. "Is the MBA DOA?" BC Business (February): Vol 33, Issue 2, 15.

12. Merritt, Jennifer. 2005. "MBA Applicants Are MIA.” Business Week (April 18): Issue 3929, 28(4).

13. Middleton, Diana. 2004. "Is the Focus Too Fine?" Business Week (October 18): Issue 3904, 92.

14. Navarro, Peter. 2004. "Why Johnny Can’t Lead." Harvard Business Review (December): Vol. 82, Issue 12, 17.

15. Porter, L.W., \& McKibbin, L.E. 1988. Management Education and Development: Drift or Thrust into the $21^{\text {st }}$ Century? New York: McGraw-Hill.

16. Stern, Stefan. 2004. "MBAs With a Heart." Management Today (October): 4 (2).

17. The Economist. 2005. "Bad for Business?" The Economist (February 19): Vol. 374, Issue 8414, 57(2).

18. Tyson, Laura D'Andrea. 2005. "On Managers Not MBAs." Academy of Management Learning \& Education (June): Vol. 4, Issue 2, 235(2). 
$\underline{\text { Notes }}$ 